\title{
Pašvaldību tiesību realizācijas problemātika Latvijas ostu tiesiskās aizsardzības jomā
}

\author{
Mg. iur. Aldis Dreiblathens \\ Rìgas Stradiṇa universitāte, Doktorantūras nodaḷa, \\ Juridisko zinātñu programma, Latvija \\ aldis.dreiblathens@gmail.com
}

\section{Kopsavilkums}

Kuǵošanas drošības nodrošināšana ir viens no vissvarīgākajiem aspektiem jūras transportā, jo no tās atkarīga gan kuǵu apkalpju, gan pasažieru drošība un dzīvība, kā arī kug̣u kravas un jūras vides saglabāšana un ostu iekārtu aizsardzība.

Šis pētījums veikts ar mērḳi apzināt, vai pastāv normas, kuras būtu svītrojamas no ostu noteikumiem, un vai tās ir jāmaina vai jāpilnveido, kā arī pētīt ostas noteikumu izdošanas kārtību Latvijā un noskaidrot, kurai institūcijai būtu jāizdod ostu noteikumi, lai efektīvi ieviestu starptautisko normu rekomendācijas un prasības.

Darba mērḳis ir analizēt Latvijas Republikas spēkā esošos normatīvos aktus, kas regulē kuǵošanas drošības un kontroles dienestu darbību valsts jūras teritorijā un ostās un uz kuru pamata kontroles dienesti veic kuǵošanas noteikumu kontroli.

Atslēgvārdi: pašvaldība, kuǵošanas tiesiskā aizsardzība, kuǵošanas drošība.

\section{levads}

Starptautiskās Jūrniecības organizācijas (IMO') [1] 2002. gada 9.-13. decembra dalībvalstu diplomātiskajā konferencē Londonā tika pieṇemta virkne grozījumu 1974. gada SOLAS konvencijā². Starp tiem viens no svarīgākajiem ir Starptautiskā kuǵu un ostas iekārtu aizsardzības kodeksa (ISPS code $\left.{ }^{3}\right)$ pieṇemšana. Kodeksa pirmā jeb A sadaḷa

${ }^{1}$ IMO - International Maritime Organization.

${ }^{2}$ SOLAS konvencija - Starptautiskā konvencija par cilvēku dzīvības aizsardzību uz jūras (International Convention for the Safety of Life at Sea).

${ }^{3}$ ISPS code - International Ship and Port Facility Security Code. 
(obligātā) ietver detalizētas aizsardzības prasības, kuras jāveic valstu valdībām, ostu pārvaldēm un kuğošanas kompānijām. Otrā jeb B sadaḷa (rekomendējošā) ietver rekomendācijas, kā izpildìt A sadal̦as prasības.

Atbilstīgi ISPS kodeksam atsevišșus pienākumus, kas saistīti ar aizsardzību, dalībvalstis drīkst delegèt atzītām aizsardzības organizācijām, izṇemot šādus uzdevumus:

- piemērojamā aizsardzības līmeņa noteikšanu;

- ostas iekārtas aizsardzības novērtēšanu un apstiprinātā novērtējuma grozījumu apstiprināšanu;

- to ostas iekārtu noteikšanu, kurām nepieciešams nozīmēt ostas aizsardzības virsnieku;

- ostas iekārtas aizsardzības plāna un apstiprinātā plāna grozījumu apstiprināšanu;

- kontroles un pārbaudes pasākumu realizāciju saskaṇā ar XI-2/9 noteikumu ieviešanu;

- Aizsardzības deklarācijas prasību ieviešanu [9].

Ostas iekārtai jādarbojas atbilstoši noteiktajiem aizsardzības līmeṇiem tajā dalībvalstī, kuras teritorijā tā atrodas. Aizsardzības pasākumus un procedūras ostas iekārtai jāpiemēro tā, lai pēc iespējas mazāk traucētu vai aizkavētu pasažierus, kugìi, kuğa personālu un apmeklētājus, preču kustību un pakalpojumus. Kuğošanas drošība vienmēr nesaraujami saistīta ar tās tiesisko nodrošinājumu, tādēl ir tik svarīgi pētīt un izvērtēt kugu kustības drošỉbas tiesiskā regulējuma īpatnības un pašvaldību lomu šajos procesos.

Darbā tiek pētīts ostu noteikumu izstrādes process un ostas kapteiṇa dienestu iespējas nodrošināt kuğošanas drošỉbu ostās atbilstoši tiesiskajam regulējumam, vērtēta Latvijas likumdošana (jūrniecības jomā), likumu atbilstîba starptautiskajām tiesību normām, kā arī Latvijas lielo ostu noteikumu izdošanas kārtība. Tiek apzināti risinājumi šo noteikumu pilnveidošanai un izteikts autora viedoklis par to, kā būtu jāveido ostas noteikumu izstrādes struktūra.

Pētījuma gaitā izmantotas analīzes un salīdzinošās metodes, kā arī darba pieredzē iegūtās zināšanas, lai izdarìtu secinājumus un izteiktu priekšlikumus darbības uzlabošanai.

\section{Latvijas normatīvo aktu analīze}

\section{Ministru kabineta noteikumi Nr. 746 “Noteikumi par kuǵu, kuǵošanas kompāniju, ostu un ostas iekārtu aizsardzības funkciju sadalijjumu, izpildi un uzraudzību" [6]}

Atbilstīgi starptautiskajām tiesību normām šie Ministru kabineta (MK) noteikumi reglamentē kuğu, kugoošanas kompāniju, ostu un ostas iekārtu aizsardzības funkciju sadalījumu, izpildes kārtību un uzraudzību; valsts akciju sabiedrības "Latvijas Jūras administrācija” (turpmāk - Jūras administrācija) Kuğu un ostu aizsardzības inspekcijas (turpmāk - KOAI) un Kuğošanas drošỉbas inspekcijas (turpmāk - KDI) inspektoru 
tiesības un pienākumus; prasības starptautiskā kug̣a aizsardzības sertifikāta, starptautiskā kug̣a aizsardzības pagaidu sertifikāta, ostu un ostas iekārtu aizsardzības atbilstības apstiprinājuma saṇemšanai, kā arī šo sertifikātu un to apstiprinājuma izsniegšanas un anulēšanas kārtību; prasības ostu vai ostas iekārtas personāla mācību programmu apstiprināšanai un to apstiprināšanas kārtību; pamatprasības kug̣u un kuğošanas kompāniju, ostu un ostas iekārtu aizsardzības apmācībām, vingrinājumiem un mācībām; prasības kuğu, kuğošanas kompāniju, ostu un ostas iekārtu aizsardzības noteikumu izpildē iesaistìto institūciju sadarbībai un informācijas apmaiṇai, kā arī sadarbības un informācijas apmain, kas kārtỉbu.

Atbilstoši šiem MK noteikumiem Kuǵu un ostu aizsardzības inspekcija uzrauga šādu normatīvo aktu prasību (aizsardzības prasību) ievērošanu:

- Eiropas Parlamenta un Padomes 2004. gada 31. marta Regula (EK) Nr. 725/2004 par kuğu un ostas iekārtu drošỉbas pastiprināšanu;

- 1974. gada Starptautiskā konvencija par cilvēku dzīvības aizsardzību uz jūras, ar turpmākajiem grozijumiem (SOLAS konvencija, XI - 2. nodal̦a);

- Starptautiskais kugu un ostas iekārtu aizsardzības kodekss (ISPS kodekss);

- Latvijas normatīvie akti, kas saistīti ar kuğu, ostu un ostas iekārtu aizsardzību.

\section{Latvijas pašvaldību saistošie noteikumi ostas aizsardzības drošībai un apsardzei}

Likuma "Par pašvaldībām" 12. pantā [7] noteikts, ka pašvaldības savas administratīiās teritorijas iedzīvotāju interesēs var brīvprātīgi realizēt savas iniciatīvas ikvienā jautājumā, ja tas nav Saeimas, Ministru kabineta, ministriju, citu valsts pārvaldes iestāžu, tiesas vai citu pašvaldību kompetencē, vai arī, ja šāda darbība nav aizliegta ar likumu. Turklāt savu funkciju izpildes nodrošināšanai likumā noteiktajos gadījumos pašvaldības ir tiesīgas izdot saistošos noteikumus. Ar Likuma par ostām 6. pantā noteikto, pašvaldībām tiek dots pilnvarojums izdot ostas noteikumus saistošo noteikumu veidā, ko pašvaldības arī realizē. Taču Valsts pārvaldes iekārtas likuma 40. panta pirmajā daḷā arī noteikts, ka publiska persona var delegeèt privātpersonai un citai publiskai personai (turpmāk - pilnvarotā persona) pārvaldes uzdevumu, ja pilnvarotā persona šo uzdevumu var veikt efektīvāk [10]. Atslēgvārds šajā normā - efektīvāk. Jautājums ir šāds: vai pašvaldības, izdodot ostu noteikumus, efektīvi realizē starptautisko organizāciju un konvenciju, piemēram, IMO, ISPS, HELCOM (Helsinku konvencija) rekomendāciju, regulu un direktīvu ieviešanu ostu tiesiskās aizsardzības jomā? Vai vietējā pašvaldība, kuras pamatintereses ir uzṇēmējdarbības veicināšana, efektīvi var ieviest tiesību normas, kas ir pretrunā ar pašvaldības pamatinteresēm? Atbilde ir: šādu normu ieviešana ir formāla, un starptautisku organizāciju, regulu, direktīvu, kā arī starptautiskās konvencijās izvirzītie mērḳi netiek sasniegti. 


\section{Ostas noteikumi}

Latvijas ostu tiesiskie pamati noteikti Jūrlietu pārvaldes un jūras drošības likumā [2]. Atbilstīgi šim likumam kuğošanu Rìgas ostā reglamentē 2006. gada 7. marta Rīgas domes saistošie noteikumi Nr. 42 "Rīgas brīvostas noteikumi”, kas izdoti saskaṇā ar Likuma par ostām 6. panta pirmo dal̦u. Rīgas brīvostas noteikumi nosaka Rìgas brīvostas iekšējo kārtību un kuğošanas drošîbu Rīgas brīvostas akvatorijā [8].

Kuğošanu Ventspils ostā reglamentē 2005. gada 21. novembra Ventspils domes saistošie noteikumi Nr. 5 "Ventspils brīvostas noteikumi”, kas izdoti saskañā ar Likuma par ostām 6. pantu, un tie nosaka Ventspils brīvostas iekšējo kārtỉbu un kuğošanas drošỉbu Ventspils brīvostas akvatorijā [11].

Kuğošanu Liepājas ostā reglamentē 2007. gada 20. decembra Liepājas pilsētas domes saistošie noteikumi Nr. 23 "Liepājas ostas noteikumi” [3].

Visu trīs Latvijas lielo ostu darbību regulējošais likumdevējs ir attiecīgās pilsētas pašvaldỉba.

Ostas noteikumos ir iekḷautas vairākas aizsardzības prasības ostas nomniekiem un komersantiem, kuri veic darbības ostas teritorijā un uz kugiem. Noteikumiem jānodrošina prasību tiesiskais pamats, lai varētu veikt operatīvās darbības un uzlabotu aizsardzības kopumu visas ostas teritorijā un nodrošinātu ātrāku un efektīvāku Eiropas Parlamenta un Padomes Direktīvas 2005/65/EK "Par ostas aizsardzības pastiprināšanu" ieviešanu. Ostas noteikumos ir noteiktas lielas tiesības ostas aizsardzības virsniekam, kurš var uzturēt, kontrolēt un uzlabot ostas aizsardzību noteiktos ostas darbỉbas posmos.

Liepājas speciālās ekonomiskās zonas (Liepājas SEZ) pārvalde, pamatojoties uz Likuma par ostām 7. panta otrās daḷas 3. punktu, ir izstrādājusi Liepājas ostas režīma noteikumus [4], atbilstoši kuriem visiem ostas nomniekiem ir jāizstrādā ostas iekārtas (termināḷu) režīma noteikumi, kas nedrīkst būt pretrunā ar Liepājas ostas režīma noteikumiem. Nomnieku izstrādātos režīma noteikumus apstiprina Liepājas Robežsardzes robežkontroles punkts un Liepājas SEZ pārvalde. Režīma noteikumu izstrāde ir obligāta visiem ostas nomniekiem, kā arī personām, kam nav saistošs ISPS kodekss. Režīma noteikumos tiek noteikta kārtība, kā darbojas caurlaižu režìms un kā notiek preču kustība ostas iekārtā (terminālī).

Vienoto caurlaižu kontroli, izgatavošanu un uzskaiti nodrošina Liepājas SEZ pārvalde. Tikai pārvalde ir tiesīga izdot vienotās Liepājas ostas caurlaides un lemt par caurlaides pielaides līmeni, noteikt, kuras caurlaides ir derīgas visā ostas teritorijā. Caurlaižu pielaides līmen̦i ir balstīti uz "triju zonu principa". Zaḷās caurlaides tiek izsniegtas viesiem, dzeltenās - biroju darbiniekiem un citiem, kam nav jāveic darbības ierobežotas piekḷuves zonās, savukārt sarkanās caurlaides saṇem darbinieki, un viniem atḷauts pārvietoties visā ostas teritorijā, tajā skaitā ierobežotas piekḷuves zonās. 
Analizējot jūrniecību reglamentējošos normatīvos aktus, jāsecina, ka valsts, pildot IMO rekomendācijas, ISPS prasības, kā arī Eiropas Parlamenta un Padomes direktīvas un regulas, jūrniecības nozares kuğošanas drošîbas uzraudzību un kuğošanas aizsardzību ir delegéejusi VAS "Latvijas Jūras administrācijai”, kas arī atbilst starptautiskajai jūras praksei.

Tādējādi ostas aizsardzību reglamentējošajā LR likumdošanā, piemēram, Jūrlietu pārvaldes un jūras drošỉbas likumā, Jūras kodeksā, MK noteikumos Nr. 683 "Kuǵa aizsardzības trauksmes signālu sakaru tīkla darbības nodrošināšanas kārtība", MK noteikumos Nr. 158 "Noteikumi par kuğošanas līdzekḷu satiksmi iekšējos ūden,os", MK noteikumos Nr. 508 "Kuğu kontroles, pārbaudes un aizturēšanas kārtība Latvijas ūden,os" jūrniecības nozares uzraudzība un kuğošanas drošība, kā arī kuğošanas aizsardzība ir delegeèta VAS "Latvijas Jūras administrācijai", izṇemot vienu ḷoti būtisku aspektu - saskaṇā ar Likuma par ostām 6. panta pirmo dalı ostas noteikumu izdošana, kas ir kuğošanas drošỉbas un kugóšanas aizsardzības neatṇemama sastāvdaḷa, tiek deleǵêta pašvaldībām.

Tātad kugoošanas drošība un ostas iekārtas aizsardzība galvenokārt ir uzticēta ostas piestātṇu nomniekiem, kas ir pretrunā ar ISPS kodeksu.

\section{Secinājumi un priekšlikumi}

Likuma "Par pašvaldībām" 14. panta trešajā dal̦ā noteikts, ka savu funkciju izpildes nodrošināšanai likumā noteiktajos gadỉjumos pašvaldības izdod saistošos noteikumus. Atbilstīgi likuma "Par pašvaldībām" 43. panta trešajā un ceturtajā dạ̦ā noteiktajam dome var pieñemt saistošos noteikumus, lai nodrošinātu pašvaldỉbas autonomo funkciju (likuma "Par pašvaldībām" 15. pants, 17.2 pants (papildu funkcijas attiecībā uz Rīgas pilsētu)) un brīvprātīgo iniciatīvu izpildi, savukārt pildot delegètās valsts pārvaldes funkcijas un pārvaldes uzdevumus, dome var pieņemt saistošos noteikumus tikai gadījumos, ja tas paredzēts likumā vai Ministru kabineta noteikumos. Atbilstoši Likuma par ostām 6. panta pirmajai daḷai [5] ostas noteikumu projektu jāizstrādā ostas pārvaldei un pēc saskaņošanas ar Satiksmes ministriju pašvaldības dome noteikumus var izdot saistošo noteikumu veidā. Latvijas lielo ostu noteikumos noteikts, ka ostas kapteinis ir ostas pārvaldes amatpersona, kas atbilstoši normatīvajiem aktiem, Starptautiskās jūras organizācijas normatīvajiem aktiem, Helsinku konvencijas un Helsinku komisijas rekomendāciju prasībām organizē un kontrolē kug̣u satiksmi ostā un ostas pievadceḷos, veic kuǵošanas drošîbas kontroles funkcijas attiecībā uz kug̣u satiksmi ostā, tās akvatorijā, kugú ceḷos, piestātnēs un terminālos.

Tādējādi nepārprotami ir norādīts, ka kuǵošanas drošība nav nodalāma no ostas iekārtas un kuğošanas aizsardzības un ostas kapteinis ir atbildīgs par ostas iekārtu aizsardzību. No tā izriet, ka ostas aizsardzības virsnieks, kurš arī atbilstoši starptautiskiem normatīviem aktiem ir ostas iekārtas aizsardzības amatpersona, nevar tikt nodalīts atseviški no ostas kapteiṇa dienesta, viņam ir jābūt pakḷautam ostas kapteinim. Savukārt ostas kapteiṇa dienesti nevar būt ostu pārvalžu pakḷautībā pēc būtîbas, jo to galvenā 
funkcija ir kug̣ošanas drošības garantēšana un ostas iekārtas aizsardzība, bet, piemēram, Liepājas SEZ galvenā funkcija ir pašvaldības administratīvās teritorijas attīstība, uzṇēmējdarbības attīstība un investīciju piesaiste. Šeit ir saskatāmas pretrunas iestādes un tās struktūrvienības darbības mērḳos, jo dažkārt piestātṇu nomnieku intereses nesakrīt ar ostas kapteiṇa dienesta interesēm, un rezultātā tiek apdraudēta kuğošanas drošỉba, cilvēku dzīvība uz jūras, un rodas apkārtējās vides piesārṇošanas draudi.

Starptautiskajos jūrniecību reglamentējošajos normatīvajos dokumentos noteikts, ka Starptautiskās Jūras organizācijas rekomendācijas, ES regulas un direktīvas uzliek par pienākumu valstij nodrošināt kuğošanas drošību ostās un ostas iekārtas aizsardzību, taču regulēts tas tiek ar pašvaldību saistošiem noteikumiem.

Ir jāmaina Likuma par ostām 6. panta pirmā dal̦a: ostas noteikumu izdošana ir jādelegēe Satiksmes ministrijas pakḷautībā esošajai VAS "Latvijas Jūras administrācijai”, un ostas noteikumu projekts ir jāizstrādā ostas kapteiṇa dienestam. Ostas kapteiṇa dienestiem jābūt tikai Latvijas Jūras administrācijas pakḷautībā, un ostas aizsardzības virsniekam ir jābūt ostas kapteiņa dienesta un tātad arī Latvijas Jūras administrācijas amatpersonai.

\section{Problems of Local Rights Issues for Legal Protection of Latvian Ports}

\section{Abstract}

The Latvian ports as a key shipping part are severable from the international law of the sea. Port rules are studied in the development process and Harbor master's authority's capabilities to ensure maritime safety in ports under legal regulation. The study was conducted with the aim of identifying whether there are rules which should be removed from the port rules and whether they are to be changed or improved.

Hypothesis: maritime security assurance is a precondition for the safety of navigation and the legislation regulating the operation of the port in conformity with the requirements of international regulatory enactments.

Keywords: local government, maritime legal protection, maritime safety.

\section{Literatūra}

1. IMO rekomendācijas. International Maritime organization. Iegūts no: http://www.imo.org/en/ About/Conventions/Pages/Home.aspx [sk. 23.04.2017.].

2. Jūrlietu pārvaldes un jūras drošības likums: Latvijas Republikas likums: pieṇemts 31.10.2002. un stājas spēkā 03.12.2002. Latvijas Vēstnesis. 168(2743), 19.11.2002. Iegūts no: http://likumi.lv/ doc.php?id =68491 [sk. 23.04.2017.]. 
Aldis Dreiblathens. Pašvaldību tiesību realizācijas problemātika

Latvijas ostu tiesiskās aizsardzības jomā

3. Liepājas ostas noteikumi: Liepājas pilsētas domes saistošie noteikumi Nr. 23: pieṇemti 20.12.2007. un stājas spēkā 02.02.2008. Latvijas Vēstnesis. 18(3802) 01.02.2008. Iegūts no: http://likumi.lv/doc.php?id=170217 [sk. 23.04.2017.].

4. Liepājas ostas režīma noteikumi. Liepājas speciālā ekonomiskā zona. 2012. Iegūts no: http:// liepaja-sez.lv/uploads/assetDocument/source/58c7cff25f334.pdf [sk. 23.04.2017.].

5. Likums par ostām: Latvijas Republikas likums: pieṇemts 22.06.1994. un stājas spēkā 26.07.1994. Latvijas Vēstnesis. 80(211), 12.07.1994. Iegūts no: https://likumi.lv/doc.php?id=57435 [sk. 23.04.2017.].

6. MK noteikumi Nr. 746 "Noteikumi par kug̣u, kug̣ošanas kompāniju, ostu un ostas iekārtu aizsardzības funkciju sadalījumu, izpildi un uzraudzību”. Pieṇemti 22.12.2015. un stājas spēkā 31.12.2015. Latvijas Vēstnesis. 254(5572), 30.12.2015. Iegūts no: https://likumi.lv/ta/id/278913noteikumi-par-kugu-kugosanas-kompaniju-ostu-un-ostas-iekartu-aizsardzibas-funkciju-sadalijumu-izpildi-un-uzraudzibu [sk. 23.04.2017.].

7. "Par pašvaldībām”: Latvijas Republikas likums: pieṇemts 19.05.1994. un stājas spēkā 09.06.1994. Latvijas Vēstnesis. 61(192), 24.05.1994. Iegūts no: https://likumi.lv/doc.php?id=57255 [sk. 23.04.2017.].

8. Rīgas brīvostas noteikumi: Rīgas pilsētas domes saistošie noteikumi Nr. 42: pieṇemti 07.03.2006. un stājas spēkā 06.04.2006. Latvijas Vēstnesis. 55(3423) 05.04.2006. Iegūts no: http://likumi.lv/doc.php?id=132075 [sk. 23.04.2017.].

9. Starptautiskais kuǵu un ostas iekārtu aizsardzības kodekss: starptautisks dokuments: pieṇemts 12.12.2002. un stājas spēkā 01.07.2004. Latvijas Vēstnesis. 100(3048), 28.06.2004. Iegūts no: https://likumi.lv/ta/lv/starptautiskie-ligumi/id/1506 [sk. 23.04.2017.].

10. Valsts pārvaldes iekārtas likums: Latvijas Republikas likums: pieṇemts 06.06.2002. un stājas spēkā 01.01.2003. Latvijas Vēstnesis. 94(2669), 21.06.2002. Iegūts no: https://likumi.lv/doc. php?id=63545 [sk. 23.04.2017.].

11. Ventspils brīvostas noteikumi: Ventspils pilsētas domes saistošie noteikumi Nr. 9: pieṇemti 02.03.2012. un stājas spēkā 18.04.2012. Latvijas Vēstnesis. 59(4662) 17.04.2012. Iegūts no: http://likumi.lv/doc.php?id=246598 [sk. 23.04.2017.]. 